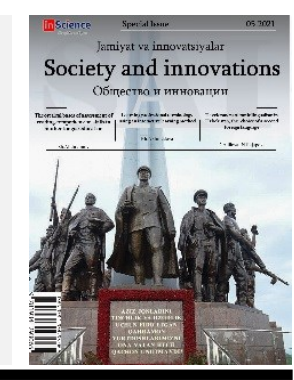

\title{
Enforcement of intellectual property rights within the scope of the TRIPS agreement (trademarks and geographical indications)
}

\section{Temurbek MUKHAMMEDOV ${ }^{1}$}

Tashkent State University of Law

\begin{tabular}{l} 
ARTICLE INFO \\
\hline Article history: \\
Received April 2021 \\
Received in revised form \\
20 April 2021 \\
Accepted 15 May 2021 \\
Available online \\
25 June 2021 \\
\\
\hline Keywords: \\
TRIPS, \\
intellectual property, \\
fair and equitable \\
procedures, \\
evidence, \\
injunctions, \\
damages.
\end{tabular}

ABSTRACT

The article analyses the certain provisions of the TRIPS agreement related to the enforcement of intellectual property rights, in particular trademarks and geographical indications by giving legal commentaries as well as by comparing with the existent civil and civil-procedural laws of Uzbekistan.

2181-1415/C) 2021 in Science LLC.

This is an open access article under the Attribution 4.0 International (CC BY 4.0) license (https://creativecommons.org/licenses/by/4.0/deed.ru)

\section{SUMMARY}

The Agreement on Trade-Related Aspects of Intellectual Property Rights (the TRIPS Agreement) is one of the fundamental documents of the World Trade Organization (WTO). This agreement introduces mandatory minimum standards for the legal protection of basic intellectual property, that is, standards for the protection of intellectual property in international trade. The TRIPS Agreement was adopted during the 1994 Uruguay Phase of the General Agreement on Tariffs and Trade (GATT).

As indicated in the preamble of the TRIPS Agreement, the main purpose of the adoption of this Agreement is to reduce barriers to international trade, taking into account the need for effective and adequate protection of intellectual property rights and measures to enforce them. The Agreement also aims to prevent the processes themselves from becoming a barrier to legitimate international trade. The agreement promotes

\footnotetext{
${ }^{1}$ LLM student in Intellectual Property and Information Technology Law, Tashkent State University of Law Scientific supervisor: PhD in law Iroda Yakubova
} 
technical development, widespread dissemination of modern technologies in the interests of creators and users of technological science, as well as the achievement of the socioeconomic well-being and a balance of rights and obligations.

Currently, the study of the TRIPS Agreement is of interest for Uzbekistan, since it is on the verge of accession to WTO. This article provides a general overview of certain articles of the TRIPS Agreement which deal with enforcement issues, in particular the civil and civil-procedural aspects thereof. Alongside the legal commentaries, the author compares the civil and procedural norms of the national legislation.

\section{ТРИПС (товар белгилари ва географик кўрсаткичлар) шартномаси доирасида интеллектуал мулк хуқуқларни таъминланиши}

Калит сўзлар:

ТРИПС,

интеллектуал мулк,

адолатли процедуралар,

даллилар,

суд тақиқлари,

зарар.

\begin{abstract}
АННОТАЦИЯ
Мақолада ТРИПС шартномасининг интеллектуал мулк хуқуқларини, хусусан, товар белгилари ва географик кўрсаткичларга бўлган хуқуқларни химоя қилишга оид айрим моддаларининг қонуний шархлар бериш, шунингдек, Ўзбекистон Республикасининг амалдаги фуқаролик ва фуқаролик процессуал қонуничилиги билан қиёсий тахлилқ қилинган.
\end{abstract}

\section{Обеспечение прав на интеллектуальную собственность (товарные знаки и географические указания) в рамках соглашение ТРИПС}

\author{
Ключевые слова: \\ ТРИПС, \\ интеллектуальная \\ собственность, \\ справедливые и \\ равноправные процедуры, \\ доказательства, \\ судебные запреты, \\ ущерб.
}

\begin{abstract}
АННОТАЦИЯ
В статье анализируются отдельные статьи соглашения ТРИПС, касающиеся защиты прав интеллектуальной собственности, в частности как права на товарные знаки и географические указания, путем предоставления юридических комментариев, а также сравнения с действующим гражданским и гражданско-процессуальным законодательством Узбекистана.
\end{abstract}

\section{THE CONCEPT OF A FAIR AND EQUITABLE PROCESS.}

Article 42 of the Agreement obliges Member States to ensure the availability of appropriate civil judicial proceedings. Although this obligation is not too burdensome for states, countries with strong administrative law enforcement systems, such as China, may need to adapt their legislation to this norm $[8,7]$. Literally interpreting the proposals of the article, it requires Member States to exclude all procedural actions not taken by the judiciary. However, the norm in the article does not apply to certain administrative and 
procedural actions (for example, provisional measures), if it is possible to appeal these actions to a higher authority. The term "right holder" used in this article refers to federations or associations such as copyright collecting societies that are recognized to have legal standing to file a joint action.

In addition to the obligation to ensure an appropriate civil proceeding, Article 42 details a number of other procedural actions. The words used in the Article are general in nature and allow Member States to dispose a flexible approach to their application. These elements in the Article are intended to protect the interests of both sides of the process or one of them. A "fair and equitable process" includes:

(a) Respondents have the right to receive a written notice detailing the grounds for a claim in a timely manner. This obligation means that the respondent should be allowed to present his defence.

(b) An independent legal counsel acts as a representative on behalf of the parties. This is would be of facultative nature for the parties. An important aspect of this obligation is that if a legal entity in the country where the proceedings are being conducted does not have a domicile, it may, at its discretion, act through a legal representative. At the same time, this right does not exclude the requirement of mandatory participation in court, and it should not be overcomplicated for the parties.

(c) All parties must have the right to substantiate their arguments and produce evidence relevant to the whole case. The right to justify arguments is important for a given due process $[8,8]$. National laws may provide that this right may also be granted to third parties involved in a case.

(d) Article 42 provides for the disclosure and protection of confidential information during proceedings, provided that it does not conflict with existing constitutional requirements. The protection of such information is widely recognized in civil proceedings, but in some jurisdictions, it may be contrary to constitutional law and be prohibited. The fact that constitutional requirements are included in the Article means that the requirements depicted in Article 42 of the TRIPS Agreement should only be of "constitutional" character. The word "constitutional" in the Article can be interpreted in different ways. It may also mean principles in the constitutional framework of a state or a law governing these relations. The word "existing" in the context of this Article means a law that applies with regards to confidentiality.

\section{EVIDENCE.}

In case of violation of intellectual property rights, it is important to have evidence in order to substantiate the claim. Although this rule is mainly important for the plaintiff, Article 43[2, 339] of the Agreement applies equally to both parties. In some cases, the respondent needs to have evidence available to the plaintiff in order to defend himself and substantiate his arguments.

The presentation of evidence during the process varies from State to State. In some cases, judicial requests for evidence can only be made if there is a risk of loss of the evidence which is in the control of the opposing party. In other cases, a request for evidence is made to determine if there has been an offense. Article 43 provides for the former, but does not exclude the latter, since, in accordance with Article 1 of the TRIPS Agreement, Member States may establish extensive protection than the legal protection 
provided for in the agreement [2,321]. In accordance with Article 43, Member States shall as a rule ensure that evidence in the control of the other party is provided if:

(a) a party has provided sufficient available evidence to support its claim; and

(b) said party has specified evidence necessary to substantiate its claim which lies in the control of the opposing party.

In accordance with paragraph 1 of Article 43, the requesting party must submit available evidence that confirms that an infringement has in fact occurred, and specify what evidence to be presented by the other party. In addition, according to this Article, the evidence presented by the opposing party should be in his control. This, in turn, would eliminate the obligation to provide evidence in possession of third parties such as suppliers or customers.

The term "evidence" in the context of Article 43 of the Agreement should be understood as documents or material evidence [3] available to the other party, including products that violate rights, or machines that produce thereof. Since the submission of such evidence may interrupt the economic activities of the party or cause economic damage, an order referred to in paragraph 1 of Article 43 must be granted in a prudent way so as to avoid abuse of rights. Article 43 does not indicate at what stage in the proceedings a request for evidence may be made by the other party. This, of course, would depend on the procedural rules established by national laws.

Article 43 also imposes certain restrictions on the submission of requests with regards to evidence which constitutes "confidential information". However, the opposing party may also request the court to reject the other party's request by referring to the fact that such information constitutes a trade secret the disclosure of which would vitiate the trade advantage. In such cases, the court should take into account the circumstances of each case. The term "appropriate case" used in the Article has a general meaning and can be interpreted in different ways. However, such interpretation should not be construed as prejudicial to the purpose of the Agreement $[1,12]$.

The second part of Article 43 of the Agreement establishes what measures Member States can take if the respondent refuses to provide evidence specified in the court's request. It is important to note that only if the opposing party refuses to provide evidence, can the court take appropriate measures [2, 339]. Article 43 Part 2 indicates three circumstances where a party to a proceeding

(a) refuses access to necessary information voluntary and without good reason;

(b) or does not provide such information within a reasonable period of time;

(c) hinders a procedure related to an enforcement action.

In the first two cases, it is obvious that requests are made on the basis of part 1 of Article 43, but since part 2 of the Article refers to "information" and not "evidence", material evidence (products, machinery etc.) are thereby excluded. Paragraph 2 of Article 43 relates only to information that is relevant to the case which is under the control of the other party. If the party refuses to provide the necessary information, the court may make preliminary and final determinations whether affirmative or negative on the basis of information presented to it, including the complaint or allegation presented by the party adversely affected by the denial of access to information [2, 339].

INJUNCTION.

The concept of injunction is existent in the legislation of the Republic of Uzbekistan. It is widespread in common law States, such as the United Kingdom, the United States, 
Australia, and New Zealand. There are provisional, initial and permanent types of injunctions [9]. Injunction is a measure that has been used by the courts in England since the time of Henry VIII, requiring the parties to refrain from certain actions. Compared to our national legislation, the measures for securing a claim set out in the Civil Procedural [3, art. 106] and Economic Procedural Codes [3, art. 94] correspond to the concept of injunction.

Both Article 44 and 50 require granting injunctions. Article 44 deals with permanent injunctions while Article 50 concerns provisional measures that might include interim injunctions $[8,11]$. Article 44 also deals with violations that occur after the import has taken place, and Article 51 of the Agreement touches upon the measures to be taken before the release of illegal goods at customs. The purpose of the measures to be taken under Article 40 is to ensure that the party refrains from unlawful acts. The phrase "the judiciary will have the appropriate powers in this regard" allows the Member States to use different approaches to achieve this goal.

The objective of Article 44 is to prevent illegal goods, i.e. goods that infringe the intellectual property rights of another person from the entry into channels of commerce, as soon as the customs clearance is carried out $[8,12]$. The exception provided for in the first part of Article 44 is not binding on bona fide owners [2, 339] A bona fide owner or acquirer is a person who acquires a good before he or she knows that the goods infringe the intellectual property rights of another person or before there is a sufficient reason to know that the handling of such goods may infringe the intellectual property rights. Injunction is not always applicable in some cases. For example, Ebay Inc. et al $\boldsymbol{V}$ Mercexchange LLC [4] May 15, 2006 the U.S. Supreme Court ruled that "the imposition of an injunction depends on the will of each district court." This means that not all intellectual property offenses are subject to judicial review.

A noteworthy aspect of Article 44 is that the second part of the Article, though the title is "injunction" it is devoted to the protection of intellectual property rights in cases where the rights of the owner are restricted by the government and related to a compulsory license $[6,255]$. The provisions of this Article are similar to those of U.S. patent and copyright law. Under U.S. law, if a government uses a patent or intellectual property without the author's consent, right holders have the right to receive an "adequate and full compensation" from the government [5, 73-80].

The basic rule of Article 44, paragraph 2, is that when a government uses a particular intellectual property object or enters into a binding license agreement, Member States may limit liability to the payment of compensation in accordance with Article $31[2,333]$ of this Agreement. This provision applies in cases where the provisions of the second section of the Agreement provide for the use of a government or third parties authorized by a government with regards to patents (Article 31) and layout-designs of integrated circuits (Article 37.2) $[8,13]$.

\section{DAMAGES.}

The amount of damages and compensation varies from law to law, depending on the type of intellectual property. Article 45 of the TRIPS Agreement defines damages as a mandatory method of law enforcement. Under this Article, the judicial bodies have the power to impose an obligation on the infringer to pay the amount of damages necessary to compensate the right holder. Compensation is also set out in the Uzbek legislation. In 
particular, according to Article 1107 of the Civil Code of the Republic of Uzbekistan, a person who uses a trademark illegally must stop the violation and pay damages to the owner of the trademark. The amount required is determined by the Member States in their legislation. However, the infringer is not liable for compensation if he did not know or could not have known that he was committing acts that infringe the rights of others. However, the provisions of Article 37.1 (related to the topography of the integrated circuits) of the Agreement oblige the payment of damages even by a bona fide acquirer.

Under the second part of Article 45, Member States may authorize the courts to recover the costs of hiring a lawyer from the infringer. This norm is similar to the U.S. legislation in this relationship. U.S. courts have the power to recover the costs of a lawyer at the expense of the losing party. Under the second part of this Article, a Member State's obligation under this Article shall be deemed to have been fulfilled if the courts have the authority to impose an obligation on the infringer to pay litigation costs. Similar provisions can be found in the Economic Procedural Code of the Republic of Uzbekistan [3, art. 118] where the litigation costs shall be borne by the parties to the case in proportion to the amount of satisfied claims. The Civil Procedural Code also contains provisions [3, art.138] where the court can order the payment to the other party in favour of which the decision is made all expenses incurred in the case, even if this party is exempted from the payment of litigation costs to the state.

The second sentence of the second part of Article 45 stipulates that the judicial authorities have the power to recover from the infringer the lost profit or a predetermined amount. This rule also applies to bona fide acquirer. However, Member States are not obligated to impose this norm and may prescribe the recovery of lost profits only from infringers who acted through guilt and negligence.

\section{OTHER REMEDIES.}

Section 3 of the TRIPS Agreement, in particular Article 46 obliges Member States to give the judicial authorities additional powers to take measures to deter infringements when the goods are found to be infringing the intellectual property rights of another person. Judicial authorities may eliminate the goods belonging to the infringer without any compensation by the following measures:

(a) removal of illegal goods from commercial circulation. However, this measure does not apply if the commercialization of illicit goods has not caused harm to the right holder (for example, if the illegal goods have spread to local shops not supplied by the right holder and the goods are unlikely to spread to the markets in which he is interested). In the case of a counterfeit trademark, the mere removal of a counterfeit trademark goods under Article 46 shall not be sufficient to bring such goods into free commercial circulation. The main purpose of the introduction of this rule is to combat professional counterfeiting of goods. However, Article 46 itself does not preclude the existence of cases in which the removal of counterfeit trademarks is sufficient, and the Member States is left free to determine such cases;

(b) The destruction of illicit goods, provided that this is not contrary to applicable law. This is a relatively serious sanction, and the destruction of any illicit goods may be mandatory unless otherwise provided by law. This, in turn, could lead to serious economic losses and socially questionable $[8,15]$. Illicit goods can be used as donations or used by 
the government (unless engaged in the sale of legal goods). However, the courts may take more lenient measures than destroying the goods;

(c) the withdrawal from trade of materials and accessories used in the creation of illicit goods. This measure is used when the above-mentioned materials and accessories are mainly used in the creation of illicit goods and when de-commercialization is necessary to reduce the likelihood of future violations.

In applying the measures set out in Article 46, the courts must be guided by the principle of proportionality. That is, the seriousness of the violation and the prescribed legal remedy must be proportional to each other and the interests of third parties must be taken into account.

\section{RIGHT TO INFORMATION.}

Article 47 of the TRIPS Agreement is a dispositive norm that provides for the receipt of information from the infringer. According to it, the Member States may authorize courts to order the infringer to provide with information about third parties involved in the production and distribution of illicit goods or services, provided that such measure is proportional to the seriousness of the infringement. However, since Article 47 is not binding, Member States may not delegate this authority. The powers enshrined in the Article are exclusive to the courts and apply to civil and administrative proceedings.

Under this provision of the Agreement, the obligation to provide information is always imposed on the "infringer" and not on the "defendant". This Article is also based on the principle of proportionality, i.e. the obligation to provide information arises only in the event of a serious offense. The infringer provides the relevant information directly to the right holder, not to the court. As a result, this information is not important to the court in making a decision, and the court can only issue a ruling on the matter at the request of the right holder. The content of the information provided is limited to

(a) the identification of third parties involved in the production and distribution of illicit goods or services. The infringer is not obliged to provide information about the type of business or commercial activity of third parties.

(b) Information on the distribution of illicit goods. It is difficult to define the boundaries of this information, as such information includes individuals, warehouse areas and trade, the final address of the illicit goods, and so on. Given that intellectual property rights are limited to a specific area, such information concerns the distribution of illegal goods in the jurisdiction in which the infringement occurred. We do not know how accurate this interpretation of the Article is. The provisions of Article 47 are important to the right holder in identifying the participants as well as in taking appropriate action against them and in the fight against professional illegal producers of goods [7, 209].

\section{INDEMNIFICATION.}

The issue of liability in law enforcement proceedings is twofold $[5,108]$. The right holder may use intellectual property rights intentionally and dishonestly to impede legal competition in the market. In such cases, the respondent may suffer serious economic damage when of a provisional measure forces him out of relevant market. Article 48 of the TRIPS agreement deals with this issue. It requires Member States to empower the courts to recover adequate compensation from a plaintiff who has abused his rights in favour of a respondent whose rights have been improperly restricted or limited. The abuse of rights 
is enshrined not only in this Article but also in other Articles of the TRIPS Agreement, including Article 8 (2), Article 40 (2), Article 41 (1), Article 50 (3), Article 53 (2). Part 1, Article 63, Part 1 and Article 67. In doing so, the agreement sought to balance the interests of intellectual property rights holders as well as third parties. Of course, when intellectual property rights are abused, not only does the perpetrator suffer from limited behaviour, but society is also deprived of a competitive product or service.

An important point to be clarified in Article 48 is when the right can be considered abused [7, 211]. Clearly, when a plaintiff deliberately seeks to eliminate an innocent competitor from the relevant market the right has been abused. Also, even if the plaintiff did not act dishonestly, it may be recognized as an abuse of the right if it deviated from reasonable law enforcement measures.

Article 48 embodies the general principle set out in Article 8, paragraph 2, [2, 323] of the Agreement, and, unlike Article $41[2,338]$, applies when the rights of the other party are unjustifiably enjoined or restricted in a clearly defined manner, for example, in case of injunctions. In such cases, the plaintiff must pay the respondent adequate compensation for damages. The provisions of Article 45 of the Agreement, i.e. the payment of the costs of hiring a lawyer, are also provided for in this Article [2,341].

The second part of Article 48 sets out the obligations related to the administration of any law aimed to protect or enforce intellectual property rights. The purpose of this provision is to establish liability for acts committed by public authorities and officials in bad faith. The word "law" in the context of the Article, refers to the laws officially adopted by the Parliament or the rules related to the exercise of intellectual property rights. The word law may also refer to criminal, administrative, civil, or judicial documents.

According to Article 48.2 Member States cannot exempt public authorities and officials from liability to appropriate remedial measures except where actions were taken in good faith $[8,18]$.

Under this Article, Member States shall determine in their national legislation what remedial measures may be taken in relation to public authorities and officials. Part 2 of Article 48 also applies regardless of whether public authorities and officials acted at the request of the interested party or on the basis of their authority (ex-officio), to the extent that such actions in question were made in normal course of administration of law enforcement. The obligation to prove that the actions of public authorities and officials have not been carried out in good faith rests with the party who made the allegations.

\section{References:}

1. Vienna Convention on the Law of Treaties of 1969. See Article 31. URL: https://legal.un.org/ilc/texts/instruments/english/conventions/1 1 1969.pdf

2. The Agreement on Trade-Related Aspects of Intellectual Property Rights of 1994. URL: https://www.wto.org/english/docs e/legal e/27-trips.pdf

3. The Civil Procedural Code of the Republic of Uzbekistan ("CPC") of 22 January 2018. URL: $\quad$ https://www.lex.uz/docs/3517334 for CPC; https://www.lex.uz/docs/3523895 for EPC

4. EBAY INC. et al. v. MERCEXCHANGE, L. L. C. certiorari to the united states court of appeals for the federal circuit No. 05-130. Argued March 29, 2006-Decided May 15, 2006. URL: https://supreme.justia.com/cases/federal/us/547/388/ 
5. J Dratler Jr., Intellectual Property Law: Commercial, Creative and Industrial Property. Law Journal Seminars Press., New York, 1996 p. 3394.

6. J Dreier., TRIPs and the enforcement of intellectual property rights in F Beier and G Schriker (eds), From GATT to TRIPS-The Agreement on Trade-Related Aspects of Intellectual Property Rights. Munich, Max Planck Institute for Foreign and International Patent, Copyright and Competition Law., Munich. p 456

7. D. Gervais The TRIPS Agreement. Drafting history and analysis. Sweet \& Maxwell, 2nd edition. London., $\mathrm{p} 450$

8. Carlos M. Correa., Trade Related Aspects of Intellectual Property Rights: A Commentary on the TRIPS Agreement. Chapter 13. Enforcement of Intellectual Property Rights. (Oxford Commentaries on GATT/WTO Agreements). Oxford University Press., 2007.

9. Understanding Injunctions". Insights on Law \& Society Magazine. American Bar Association. Winter 2014. Retrieved 6 September 2017. 